\title{
Rootstock Effects on Shoot Morphology and Spur Quality of 'Delicious' Apple and Relationships with Precocity and Productivity
}

\author{
Peter M. Hirst ${ }^{1}$ and David C. Ferree \\ Department of Horticulture, Ohio Agricultural Research and Development Center, The Ohio State \\ University, Wooster, OH 44691
}

Additional index words. Malus domestics, flowering, spur density, trunk cross-sectional area

\begin{abstract}
Two-year-old branch sections of 'Starkspur Supreme Delicious' apple (Malus domestics Borkh.) trees growing on 17 rootstock were studied over 6 years to determine the effects of rootstock on shoot morphology and spur quality and describe how these factors may be related to precocity and productivity. Shoot length was affected by rootstock and was positively related to trunk cross-sectional area within each year, but the slope of the regression line decreased as trees matured. The number of spurs on a shoot was largely a product of shoot length. Spur density was inversely related to shoot length, where rootstock with longer shoots had lower spur densities. Flower density was not related to spur density, and shoot length only accounted for a minor part of the variation in flower density. The proportion of spurs that produced flowers was closely related to flower density, indicating that rootstock influence flower density by affecting the development of individual buds rather than by the production of more buds. More vigorous rootstock generally had spurs with larger individual leaves and higher total leaf area per spur, but fewer spur leaves with lower specific leaf weights. More precocious rootstock were also more productive over a 10-year period when yields were standardized for tree size. Tree size was the best indicator of precocity and productivity, which could be predicted with a high degree of certainty as early as the 4th year.
\end{abstract}

Apple rootstock are used primarily for reducing tree size and increasing precocity and yield efficiency. Compared with widely spaced large trees, intensive plantings of small trees resulting from the use of dwarfing rootstock intercept more incident light, which is closely related to dry matter production (Jackson, 1980). Smaller trees generally have less internal shading. Shading in full-sized trees results in areas of the tree canopy characterized by low productivity and poor fruit quality (Ferree, 1989; Heinicke, 1964; Warrington et al., 1995). In addition to improved light interception and distribution, increased partitioning of photosynthates to fruit rather than wood also may contribute to the high yield efficiencies commonly observed with dwarfed trees (Forshey and McKee, 1970; Preston, 1958, 1968). For example, on 27 -year-old trees, the ratio of crop to the weight of trunk and branches was 13.7 for trees growing on the dwarfing rootstock, M.9, while for those growing on the vigorous M. 16 the ratio was 4.7.

Spur quality and shoot morphological attributes may be one way in which rootstock influence productivity. In the past, spur quality has been measured in terms of spur leaf number, leaf area, mean leaf size, leaf dry weight, specific leaf weight (SLW) and terminal bud diameter (Barritt et al., 1987; Ferree, 1989). Spur density (spurs $/ \mathrm{m}$ ) and the proportion of flowering spurs (flowering spurs/spur) have been used as descriptors of shoot morphology (Ketchie 1984; Warrington et al., 1990), but measurements of shoot length, spur number, flower number, flower density, and lateral shoots may enable a more complete characterization.

Received for publication 19 Sept. 1994. Accepted for publication 9 Jan. 1995. Safaries and research support provided by state and federal funds appropriated to the Ohio Agricultural Research and Development Center, The Ohio State Univ., Journal article no. 128-94. P.M. Hirst acknowledges additional support provided by The Horticulture and Food Research Institute of New Zealand. The cost of publishing this paper was defrayed in part by the payment of page charges. Under postal regulations, this paper therefore must be hereby marked advertisement solely to indicate this fact.

'Current address: The Horticulture and Food Research Institute of New Zealand Ltd., Private Bag 1401, Havelock North, New Zealand.
Spur leaf area and spur leaf size were positively related to longterm productivity (Rem and Ferree, 1984). While comparing growth characteristics of 28 'Delicious' strains, Warrington et al. (1990) found a positive relationship between spur density and yield efficiency. Among strains, spur density was related positively to vigor attributes. A comparison among nine rootstock indicated a negative relationship between spur density and vigor attributes such as spur leaf number and spur leaf area (Warrington et al., 1990). Therefore, rootstock effects on spur quality and shoot growth attributes, and the relationships between them, may not be adequately described by previous studies of cultivar effects. The objective of this study was to determine the effects of rootstock, producing a wide range of tree size, on spur quality and shoot morphology variables over several growing seasons and to describe the relationships of flowering, precocity, and productivity to these variables.

\section{Materials and Methods}

'Starkspur Supreme Delicious' apple trees growing on 17 rootstock were planted in Wooster, Ohio, as part of a rootstock evaluation program (Table 1, NC-140, 1990). The historical origin and parentage for the rootstock in this study are found in Ferree and Carlson (1987). The trees were planted in 1984 at a spacing of $3.5 \times 5.5 \mathrm{~m}$ as randomized complete blocks with 10 single-tree replications. One tree each of 'Macspur' and 'Starkspur Golden Delicious' growing on M.26 EMLA rootstock was included in each block as pollenizers. Trees were trained as central leaders and standard cultural practices were followed. As is common in Ohio, no irrigation was supplied to the trees.

In each year at bloom from 1988-93, five shoots around the periphery of each tree were selected and the 2-year-old section of wood was identified. The length of this branch section was measured and the number of flower clusters, total spurs, and lateral shoots were counted. Additionally, from 1990-93, spurs and lateral shoots were classified as either vegetative or flowering. 
Table 1. Effect of rootstock and year on vegetative and flowering characteristics of 2-year-old branches of 'Starkspur Supreme Delicious' trees over 6 years.

\begin{tabular}{|c|c|c|c|c|c|c|}
\hline Effect & $\begin{array}{c}\text { Shoot } \\
\text { length } \\
(\mathrm{cm})\end{array}$ & $\begin{array}{c}\text { Spur } \\
\text { density } \\
\text { (no./m) }\end{array}$ & $\begin{array}{c}\text { Flower } \\
\text { density } \\
\text { (clusters/m) }\end{array}$ & $\begin{array}{c}\text { Lateral } \\
\text { shoots/ } \\
\mathrm{m}\end{array}$ & $\begin{array}{c}\text { Growing } \\
\text { points/ } \\
\mathrm{m}\end{array}$ & $\begin{array}{c}\text { Flowering } \\
\text { spurs } \\
(\%)\end{array}$ \\
\hline \multicolumn{7}{|l|}{ Rootstock } \\
\hline P. 22 & 15.9 & 39.3 & 23.9 & 2.3 & 41.6 & 62.0 \\
\hline P. 16 & 22.3 & 33.9 & 20.4 & 1.7 & 35.6 & 61.8 \\
\hline P. 2 & 23.8 & 36.4 & 19.7 & 2.6 & 39.0 & 51.2 \\
\hline CG. 10 & 24.5 & 37.2 & 19.6 & 1.8 & 39.0 & 53.6 \\
\hline B.9 & 26.2 & 31.1 & 20.9 & 3.0 & 34.0 & 61.7 \\
\hline MAC.39 & 28.5 & 36.2 & 20.3 & 2.6 & 38.9 & 55.9 \\
\hline M.26EMLA & 30.4 & 36.2 & 17.5 & 1.9 & 38.1 & 49.8 \\
\hline C. 6 & 28.8 & 35.4 & 20.4 & 2.4 & 37.8 & 54.7 \\
\hline P.1 & 32.2 & 34.1 & 22.1 & 2.6 & 36.7 & 59.4 \\
\hline M.7EMLA & 34.3 & 31.7 & 21.0 & 2.7 & 34.5 & 56.6 \\
\hline M.4 & 37.6 & 33.8 & 21.0 & 2.9 & 36.8 & 54.9 \\
\hline MAC. 1 & 33.7 & 35.6 & 20.3 & 2.2 & 37.8 & 53.5 \\
\hline CG.24 & 37.8 & 36.5 & 15.7 & 1.3 & 37.9 & 42.7 \\
\hline B. 490 & 35.9 & 33.1 & 20.9 & 3.0 & 36.2 & 53.9 \\
\hline P.18 & 37.8 & 32.7 & 17.5 & 2.5 & 35.1 & 50.9 \\
\hline Ant. 313 & 38.9 & 31.8 & 16.5 & 2.6 & 34.3 & 42.9 \\
\hline Seedling & 38.1 & 34.0 & 17.5 & 1.6 & 35.6 & 48.2 \\
\hline $\operatorname{LSD}(P=0.05)$ & 2.0 & 1.7 & 3.0 & 0.6 & 1.6 & 8.8 \\
\hline \multicolumn{7}{|l|}{ Year } \\
\hline 1988 & 50.0 & 22.8 & 20.6 & 6.5 & 29.4 & --- \\
\hline 1989 & 32.5 & 30.8 & 13.2 & 4.4 & 35.2 & --- \\
\hline 1990 & 25.9 & 37.8 & 13.7 & 0.4 & 38.2 & 36.5 \\
\hline 1991 & 26.8 & 41.1 & 28.4 & 1.0 & 42.0 & 69.1 \\
\hline 1992 & 30.3 & 37.1 & 12.7 & 0.7 & 37.8 & 34.1 \\
\hline 1993 & 20.5 & 38.3 & 29.6 & 1.1 & 39.4 & 75.4 \\
\hline $\operatorname{LSD}(P=0.05)$ & 1.2 & 1.0 & 1.8 & 0.4 & 1.0 & 3.7 \\
\hline \multicolumn{7}{|l|}{ F significance } \\
\hline Rootstock & $* * *$ & $* * *$ & $*$ & $* * *$ & $* * *$ & $* * *$ \\
\hline Year & $* * *$ & $* * *$ & $* * *$ & $* * *$ & $* * *$ & $* * *$ \\
\hline Rootstock $\mathrm{x}$ year & $* * *$ & NS & $* * *$ & $* * *$ & NS & NS \\
\hline
\end{tabular}

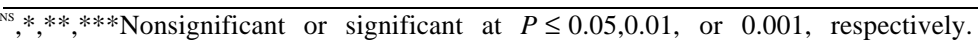

From these counts, the proportion of spurs and lateral shoots that flowered was determined, and the densities of flowers, spurs, lateral shoots, and growing points (spurs + shoots) were calculated as the number per meter of branch length. Each year, trunk diameters were measured $20-30 \mathrm{~cm}$ above the soil line from which trunk cross-sectional area (TCSA) was calculated and the total fruit yield per tree was weighed at harvest. Previously, TCSA has been found to be a good predictor of total above-ground fresh weight, and this relationship was constant among rootstock for a given cultivar (Westwood and Roberts, 1970).

An examination of the relationship between TCSA and shoot growth most appropriately involves the TCSA measured at the end of a growing season and the mean length of shoots that grew during the season. In this study, shoot morphology characteristics of 2year-old branch sections were determined; therefore, the shoot lengths that were measured actually grew 2 years previously. For this reason, shoot lengths measured 2 years previously to TCSA were used to determine this relationship.

In mid-September 1991, five vegetative spurs were sampled from each of five trees of each rootstock. The number of leaves on each spur was recorded, and spur leaf area, spur leaf dry weight, and terminal bud diameter were measured. From these measurements, SLW was calculated as leaf dry weight per unit leaf area $\left(\mathrm{mg} \cdot \mathrm{cm}^{-2}\right)$.

Weather data were obtained from a weather station located about $3 \mathrm{~km}$ from the planting site.

Data were analyzed using analysis of variance, regression analysis, and Pearson product moment correlation coefficients (Minitab, 1993). In addition, orthogonal contrasts were used to determine tree age effects (SAS Institute, 1989).

\section{Results}

Shoot length. The length of the 2-year-old branch section was influenced by rootstock, year, and the interaction between them (Table 1). Year accounted for most of the variation in length, but $80 \%$ of the yearly variation, as determined be a series of orthogonal contrasts, was due to increase shoot lengths in 1988 compared to those for 1989-93 (data not presented). The 2-year-old shoots measured in 1988 grew during 1986, which was the first year that trees cropped. Although the year $\mathrm{x}$ rootstock interaction was significant, the interaction accounted for $<10 \%$ of the treatment variation (sums of squares). TCSA increased linearly over time (Table 2) with linear coefficients of determination $>0.97$ for all rootstock, The annual TCSA increment was closely related to total TCSA for each year $\left(r^{2}>0.93\right)$.

The most dwarfing rootstock in the study clearly was P.22, which consistently had the lowest TCSA and shortest shoots (Tables 1 and 2). Overall, shoots on P.22 trees were $43 \%$ the length 
Table 2. Trunk cross-sectional area $\left(\mathrm{cm}^{2}\right)$ of 'Starkspur Supreme Delicious' trees planted in 1984 and grown on 17 rootstock.

\begin{tabular}{|c|c|c|c|c|c|c|c|c|}
\hline Rootstock & 1986 & 1987 & 1988 & 1989 & 1990 & 1991 & 1992 & 1993 \\
\hline P.22 & 8.0 & 8.1 & 9.0 & 9.9 & 10.9 & 11.7 & 12.9 & 13.5 \\
\hline P.16 & 7.6 & 8.2 & 9.4 & 12.1 & 14.1 & 15.0 & 16.6 & 18.3 \\
\hline P. 2 & 8.7 & 12.0 & 17.9 & 20.8 & 25.4 & 28.7 & 33.2 & 35.1 \\
\hline CG.10 & 14.5 & 17.0 & 19.4 & 23.6 & 27.9 & $31, .5$ & 36.1 & 39.6 \\
\hline B. 9 & 14.7 & 21.1 & 23.7 & 28.0 & 35.3 & 40.1 & 45.2 & 49.6 \\
\hline MAC.39 & 15.4 & 20.9 & 25.1 & 31.2 & 38.5 & 43.5 & 51.0 & 56.5 \\
\hline M.26EMLA & 20.3 & 29.4 & 36.6 & 46.7 & 57.1 & 63.5 & 74.0 & 80.6 \\
\hline C. 6 & 21.1 & 29.3 & 38.3 & 47.1 & 59.0 & 67.6 & 78.1 & 84.3 \\
\hline P.1 & 22.1 & 37.2 & 45.5 & 55.1 & 71.1 & 80.3 & 92.9 & 103.6 \\
\hline M.7EMLA & 23.3 & 38.5 & 46.3 & 54.2 & 83.3 & 83.2 & 96.3 & 104.9 \\
\hline M.4 & 19.7 & 35.3 & 45.4 & 56.3 & 80.4 & 91.7 & 107.7 & 120.0 \\
\hline MAC. 1 & 23.9 & 40.1 & 54.0 & 67.5 & 89.9 & 103.1 & 122.6 & 136.1 \\
\hline CG.24 & 23.1 & 40.5 & 52.8 & 67.3 & 90.6 & 104.8 & 128.4 & 139.5 \\
\hline B. 490 & 25.8 & 46.1 & 60.1 & 72.8 & 96.2 & 114.3 & 132.2 & 148.4 \\
\hline P. 18 & 21.5 & 42.5 & 54.4 & 71.2 & 100.6 & 117.8 & 140.3 & 155.6 \\
\hline Ant. 313 & 23.5 & 43.4 & 57.5 & 73.3 & 102.7 & 119.4 & 140.2 & 157.4 \\
\hline Seedling & 29.7 & 47.6 & 68.5 & 84.8 & 113.2 & 130.9 & 152.0 & 169.1 \\
\hline $\operatorname{LSD}(P=0.05)$ & 4.6 & 6.0 & 6.9 & 8.9 & 11.5 & 13.2 & 16.0 & 17.5 \\
\hline
\end{tabular}

of those growing on seedling rootstock, but ranged from $27 \%$ $50 \%$ depending on year. The rootstock with the longest shoots and highest TCSA were seedling, Ant. 313, CG.24, and P.18. More year-to-year variation in shoot length was evident in more vigorous trees $\left(r^{2}=0.77, P \leq 0.001\right)$, but in proportion to the mean the variability was similar across rootstock (data not presented). Shoot lengths were correlated highly with TCSA during the year in which they grew (for example, 1988 shoot length vs. 1986 TCSA), with all rootstock sharing a common relationship within years (Fig. 1). The slope of regression line decreased with successive years.

The relationships between shoot growth and annual TCSA increment were similar to those with TCSA, although the decrease in slope with successive years was less pronounced.

Vegetative growth. The number of spurs on a shoot was largely a function of the shoot length (Table 3). The pattern of the rootstock $\mathrm{x}$ year interaction on spur numbers per shoot varied among rootstock, which were classified into three groups based on the visual appearance of the interaction (Fig. $2 \mathrm{~A}-\mathrm{C}$ ). The first group of rootstock consisted of MAC.39, CG.10, CG.24, M.4, and Ant.313, and was characterized by gradually decreasing numbers of spurs pershoot from 1988-91 followed by a slight increase in 1992 and a distinct drop in 1993 (Fig. 2A). In each year, CG.10 had fewer spurs per shoot than CG.24, with the other rootstock generally being intermediate. Trees on rootstock MAC. 1, P.1, seedling, M.26EMLA, P.2, and P.18 formed the second group of rootstock (Fig. 2B) and had reasonably constant numbers of spurs per shoot until a marked decline in 1993. Trees on P.2 consistently had fewer spurs than the other rootstock in this group. The remaining rootstock (B.9, P.22, M.7EMLA, B.490, P.16, and C.6) exhibited maximum spur numbers in 1991 and decreases from 199 1-93 (Fig. 2C). Within this group, B.490 had the most spurs and P.22 the least.

The relationship between shoot length and shoot number differed among years, with the number of spurs for a given shoot length (that is, spur density) increasing from 1988-89 and again from 1989-90, after which the relationship was constant (Table 1). Spur density was influenced mostly by year, although minor rootstock effects were evident. Nearly $90 \%$ of the year effect was due to lower spur densities in 1988 and 1989 compared with those during 1990-93 (data not presented). Although there was some variability in the relationship between spur density and shoot length among rootstock and among years, overall a negative relationship was evident (Fig. 3, Table 3). Therefore, rootstock with longer shoots generally had fewer spurs per meter of branch length than rootstock with shorter shoots.

Shoot length data were combined across years and expressed as a percentage of the seedling value, as were data for spur numbers per shoot (Fig. 4). The position of points in relation to the line where spur numbers per shoot and shoot length are an equal percentage of seedling indicates relative spur density, where points above this line have higher spur densities than trees on seedling rootstock and points below the line are less spurry than seedling. A strong linear trend between these two variables was evident $\left(r^{2}\right.$ $=0.92, P \leq 0.001$ ), and the relationship was such that trees larger than $85 \%$ of seedling tended to have lower spur densities than seedling and smaller trees had higher spur densities (Fig. 4). Trees growing on CG.24, M.26EMLA, MAC.39, CG.10, and P.22 appeared to have the most spurs for their shoot length, and Ant.313, M.7EMLA, P. 18, and B.9 the fewest spurs. Although rootstock with shorter shoots tended to have higher spur densities, such rootstock effects were minor in magnitude with the spur density of trees on all rootstock within $15 \%$ of those for trees growing on seedling rootstock.

The number of lateral shoots growing on the 2-year-old branch section was highest in 1988 and declined steadily until 1990, after which they remained at low levels. This could not be solely attributed to increased shoot growth in 1988 and 1989, since the number of lateral shoots in relation to shoot length (lateral shoot density) showed similar, although less pronounced, trends (Table 1). Lateral shoot density was not related to shoot length in either of these years, but was positively correlated with TCSA in $1988(\mathrm{r}=$ $0.68, P \leq 0.0 .1)$ and $1989(r=-0.82, P \leq 0.01)$.

Combining data for spurs and lateral shoots to give total growing points provides a measure of the degree to which lateral buds on that portion of the branch had broken dormancy and begun. active growth. Less variation was evident among rootstock and years for the number of growing points than for the number of spurs per shoot, indicating less difference in the degree of bud break due to rootstock or year than would be indicated by spur data. Similar 


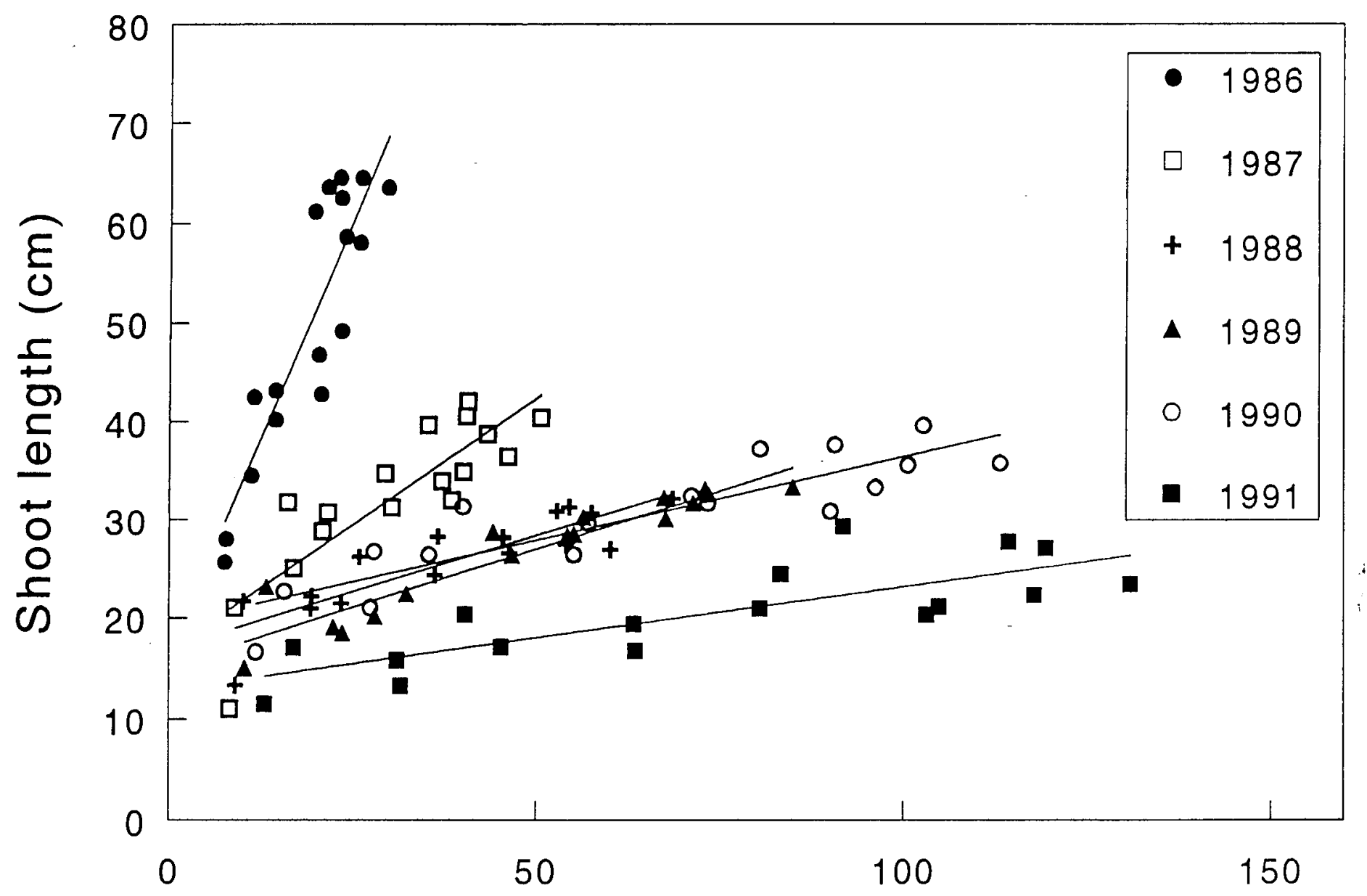

\section{$\operatorname{TCSA}\left(\mathrm{cm}^{2}\right)$}

Fig. 1. Relationship between mean yearly shoot length and trunk cross-sectional area (TCSA) for 'Starkspur Supreme Delicious' trees growing on 17 rootstock. Each point represents the mean for one rootstock for each specified year $(n=50)$.

trends were evident with number of growing points per meter, which displayed less yearly variation than spur density (mean per coefficients of variation for growing points per meter and spur density of 12 and 20 , respectively).

Flowering. Considerably more variation among years was evident in the number of flowers per shoot than for shoot length, and the rootstock $\times$ year interaction was significant for flower density (Table 1). Similar to shoot length, most of the yearly variation in flower number $(68 \%)$ was explained by the difference between 1988 and 1989-93 (data not shown). Rootstock were divided into three groups based on the visual appearance of the pattern of the interaction with year (Fig. 5.). The rootstock M.4,
M.7EMLA, B.490, and Ant.313 all had high numbers of flowers per shoot in 1988 (11-13) which declined steadily until 1990 when very few flowers were borne ( $<2$ flowers per shoot). A reasonably high number of flowers was evident in 1991 and 1993, with a slight drop during 1992 (Fig. 5A). The second group of rootstock, comprised of B.9, MAC.1, P.1, seedling, P.2, P.18, and C.6, demonstrated similar differences among years as the first group, but the fluctuations were less extreme (Fig. 5). Rootstock within this group differed widely in their effects on tree size and precocity. Generally, P.2 had the lowest number of flower clusters per shoot and trees on seedling rootstock the highest. Rootstock in both these groups (Fig. 5 A and B) demonstrated a lower degree of

Table 3. Correlation coefficients between tree size and shoot morphology characteristics.

\begin{tabular}{|c|c|c|c|c|c|c|}
\hline Characteristic & $\begin{array}{l}\text { TCSA } \\
(1993)\end{array}$ & $\begin{array}{l}\text { Shoot } \\
\text { length }\end{array}$ & $\begin{array}{c}\text { Spur } \\
\text { no. }\end{array}$ & $\begin{array}{c}\text { Spur } \\
\text { density }\end{array}$ & $\begin{array}{c}\text { Flower } \\
\text { no. }\end{array}$ & $\begin{array}{l}\text { Flower } \\
\text { density }\end{array}$ \\
\hline Shoot length & $0.95 * * *$ & & & & & \\
\hline Spur number & $0.92 * * *$ & $0.96 * * *$ & & & & \\
\hline Spur density & -0.48 & $-0.56^{*}$ & -0.33 & & & \\
\hline Flower number & $0.76^{*}$ & $0.80 * *$ & $0.71 * * *$ & $-0.61 * *$ & & \\
\hline Flower density & $4.50 *$ & $-0.55^{*}$ & $-0.59 *$ & 0.17 & 0.14 & \\
\hline Flower spurs (\%) & $4.58 *$ & $-0.61 * *$ & $4.67 * *$ & 0 & -0.20 & $-0.92 * * *$ \\
\hline
\end{tabular}

*,**,***Significant at $P \leq 0.05,0.01$, or 0.001 , respectively. 

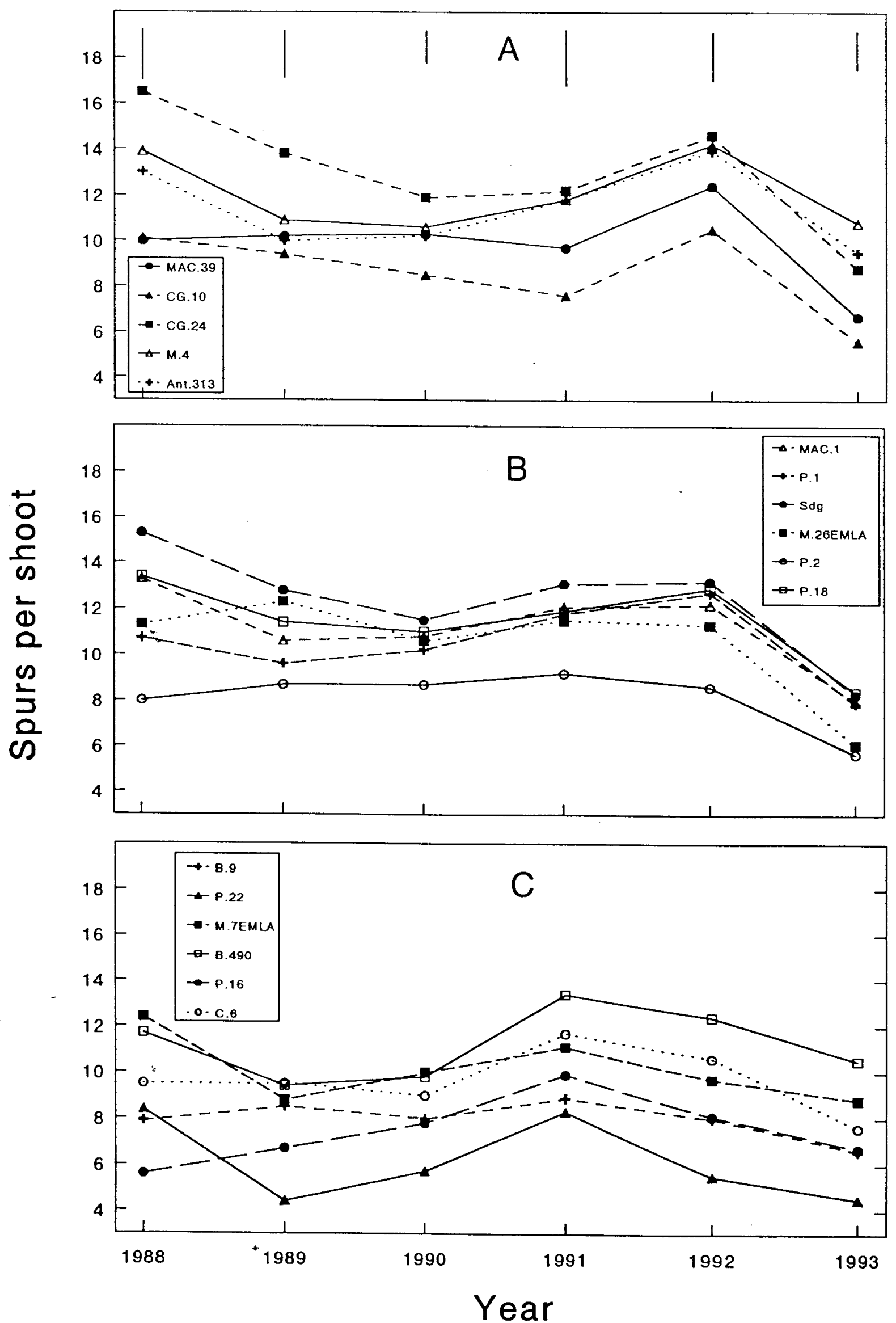

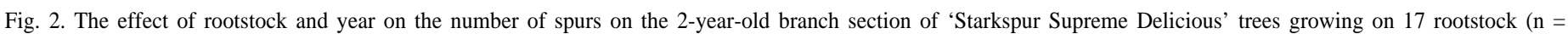
50). A, B, and $\mathbf{C}$ represent different groups of rootstock; separated on the basis of the pattern of their response to year. Bars indicate LSD $P=0.05$. 
flowering in 1990 than in either the previous or subsequent years. The remaining rootstock (MAC.39, P.22, CG.10, CG.24, M.26EMLA, and P.16) exhibited few flowers in 1989 with moderate, but variable, flowering in other years (Fig. SC). Reduced flowering in 1992 compared with 1991 and 1993 was evident for rootstock in all groups except P.22, which was lower in 1992 than in 1991 but remained at the same level in 1993. Except for 1990 and 1993, flowering each year was negatively correlated with the yield efficiency in the previous year $(1988 r=-0.82, P \leq 0.001 ; 1989$ $r=-0.69, P \leq 0.01 ; 1991 r=-0.65, P \leq 0.01 ; 1992 r=-0.63, P$ $\leq 0.01)$. strong, positive relationships of flower number with TCSA, shoot length, and spur number were evident, but trees with higher spur densities had fewer flowers (Table 3). Therefore, flower numbers were higher in more vigorous trees, as indicated by larger TCSA, longer shoots, more spurs, and lower spur densities. Relationships between shoot morphology variables and TCSA were similar to those with annual TCSA increment with similar correlation coefficients (data not presented).

Generally, flower density followed similar yearly trends as flower number, although density was relatively low in 1988, reflecting the greater shoot lengths in 1988 compared with the relatively constant lengths from 1989-93. Overall, flower density was not related to flower number or spur density (Table 3). No consistent relationship between flower density and shoot length were evident for any of the rootstock studied. However, when data from all rootstock and years were combined, negative relationships with TCSA, shoot length, and spur number were apparent (Table 3).

When flowering data were converted to a percent of seedling basis and plotted against shoot length also as a percent of seedling, it would appear that, overall, trees on Ant. 313, P.18, and CG.24 rootstock had similar shoot lengths to seedling, but fewer flowers (Fig. 6). Trees on M.26EMLA rootstock performed similarly to seedling with shoot lengths $80 \%$ that of seedling and $75 \%$ the numbers of flowers borne by trees on seedling rootstock. Trees on all other rootstock had $20 \%$ more flowers than those growing on seedling rootstock relative to their shoot lengths (Fig. 6, Table 1).

The proportion of spurs on which flowers were borne displayed a biennial pattern, with relatively few spurs flowering in 1990 and 1992 and followed by much heavier flowering in 1991 and 1993 (Table 1). Similar yearly patterns were evident for trees on all rootstock except P. 16, MAC.39, CG.10, and M.26EMLA, which produced relatively more flowers in 1990 (data not presented). The proportion of spurs bearing flowers was closely related to flower density but was negatively related to tree size, shoot length, and spur number (Table 3). Flowers are initiated during the year before they emerge, but there were no consistent relationships between flowering and the previous year's yield characteristics (data not presented).

Spur quality. The spur quality attributes measured in this study were affected by rootstock, but the differences in SLW and terminal bud diameter were small, with $14 \%$ and $15 \%$ difference between the largest and smallest rootstock for SLW and bud diameter, respectively (Table 4). Within each rootstock, few relationships were found between spur quality variables and either TCSA or shoot length, but when data from rootstock were combined some trends became apparent (Table 5). Leaf number per spur and SLW were correlated negatively with tree size, as estimated by TCSA, in 1989 when the shoot grew and in 1990 when spurs developed. Spur leaf size (leaf area per leaf) and spur

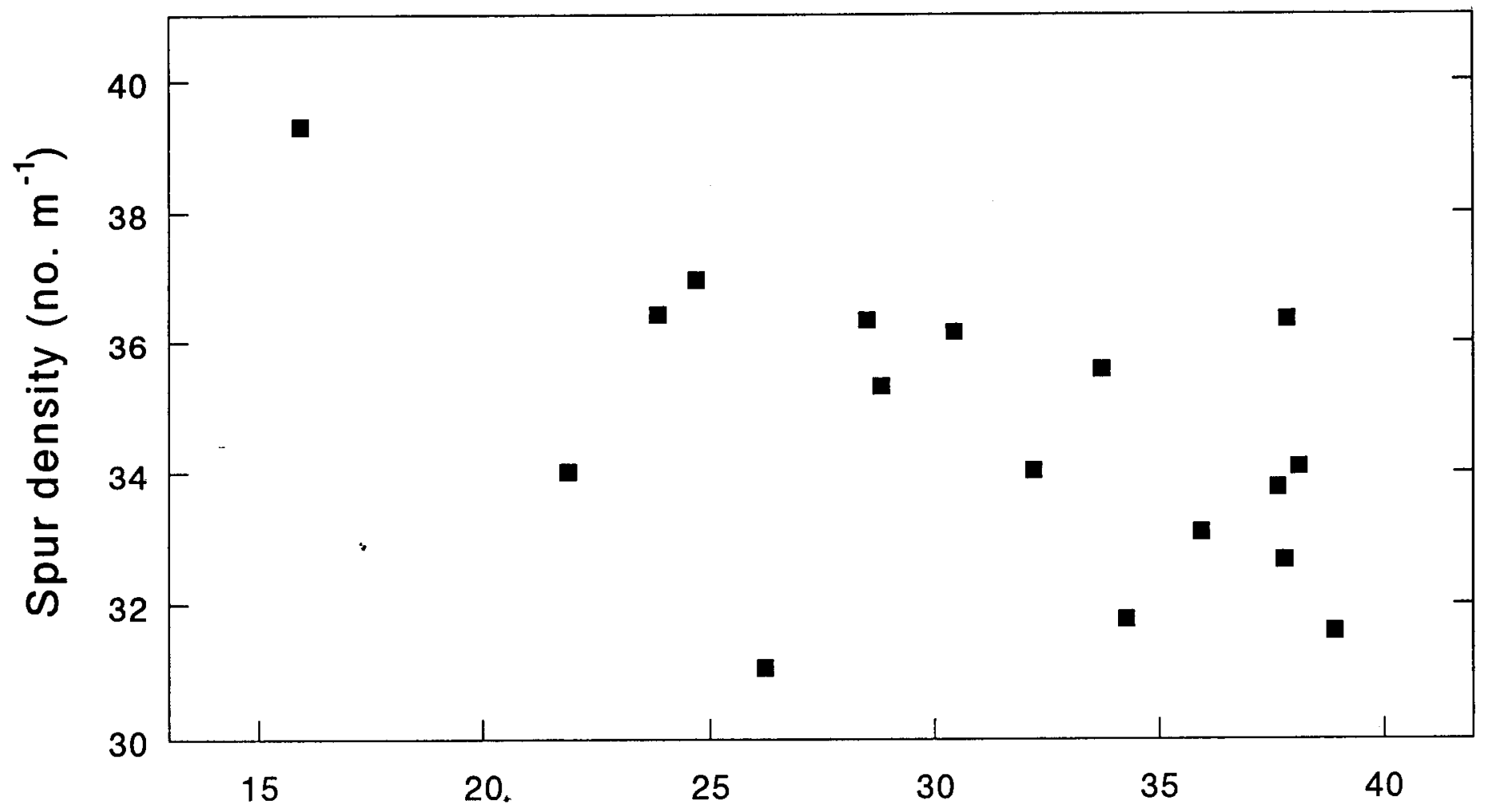

\section{Shoot length $(\mathrm{cm})$}

Fig. 3. Plot of spur density and the length of the 2-yem-old branch section for 'Starkspur Supreme Delicious' trees growing on 17 rootstock measured over 6 years (n $=300), r=0.55, P \leq 0.05$. 
flowering in 1990 than in either the previous or subsequent years. The remaining rootstock (MAC.39, P.22, CG.10, CG.24, M.26EMLA, and P.16) exhibited few flowers in 1989 with moderate, but variable, flowering in other years (Fig. SC). Reduced flowering in 1992 compared with 1991 and 1993 was evident for rootstock in all groups except P.22, which was lower in 1992 than in 1991 but remained at the same level in 1993. Except for 1990 and 1993, flowering each year was negatively correlated with the yield efficiency in the previous year $(1988 r=-0.82, P \leq 0.001 ; 1989$ $r=-0.69, P \leq 0.01 ; 1991 r=-0.65, P \leq 0.01 ; 1992 r=-0.63, P$ $\leq 0.01)$. strong, positive relationships of flower number with TCSA, shoot length, and spur number were evident, but trees with higher spur densities had fewer flowers (Table 3). Therefore, flower numbers were higher in more vigorous trees, as indicated by larger TCSA, longer shoots, more spurs, and lower spur densities. Relationships between shoot morphology variables and TCSA were similar to those with annual TCSA increment with similar correlation coefficients (data not presented).

Generally, flower density followed similar yearly trends as flower number, although density was relatively low in 1988, reflecting the greater shoot lengths in 1988 compared with the relatively constant lengths from 1989-93. Overall, flower density was not related to flower number or spur density (Table 3). No consistent relationship between flower density and shoot length were evident for any of the rootstock studied. However, when data from all rootstock and years were combined, negative relationships with TCSA, shoot length, and spur number were apparent (Table 3).

When flowering data were converted to a percent of seedling basis and plotted against shoot length also as a percent of seedling, it would appear that, overall, trees on Ant. 313, P.18, and CG.24 rootstock had similar shoot lengths to seedling, but fewer flowers (Fig. 6). Trees on M.26EMLA rootstock performed similarly to seedling with shoot lengths $80 \%$ that of seedling and $75 \%$ the numbers of flowers borne by trees on seedling rootstock. Trees on all other rootstock had $20 \%$ more flowers than those growing on seedling rootstock relative to their shoot lengths (Fig. 6, Table 1).

The proportion of spurs on which flowers were borne displayed a biennial pattern, with relatively few spurs flowering in 1990 and 1992 and followed by much heavier flowering in 1991 and 1993 (Table 1). Similar yearly patterns were evident for trees on all rootstock except P. 16, MAC.39, CG.10, and M.26EMLA, which produced relatively more flowers in 1990 (data not presented). The proportion of spurs bearing flowers was closely related to flower density but was negatively related to tree size, shoot length, and spur number (Table 3). Flowers are initiated during the year before they emerge, but there were no consistent relationships between flowering and the previous year's yield characteristics (data not presented).

Spur quality. The spur quality attributes measured in this study were affected by rootstock, but the differences in SLW and terminal bud diameter were small, with $14 \%$ and $15 \%$ difference between the largest and smallest rootstock for SLW and bud diameter, respectively (Table 4). Within each rootstock, few relationships were found between spur quality variables and either TCSA or shoot length, but when data from rootstock were combined some trends became apparent (Table 5). Leaf number per spur and SLW were correlated negatively with tree size, as estimated by TCSA, in 1989 when the shoot grew and in 1990 when spurs developed. Spur leaf size (leaf area per leaf) and spur

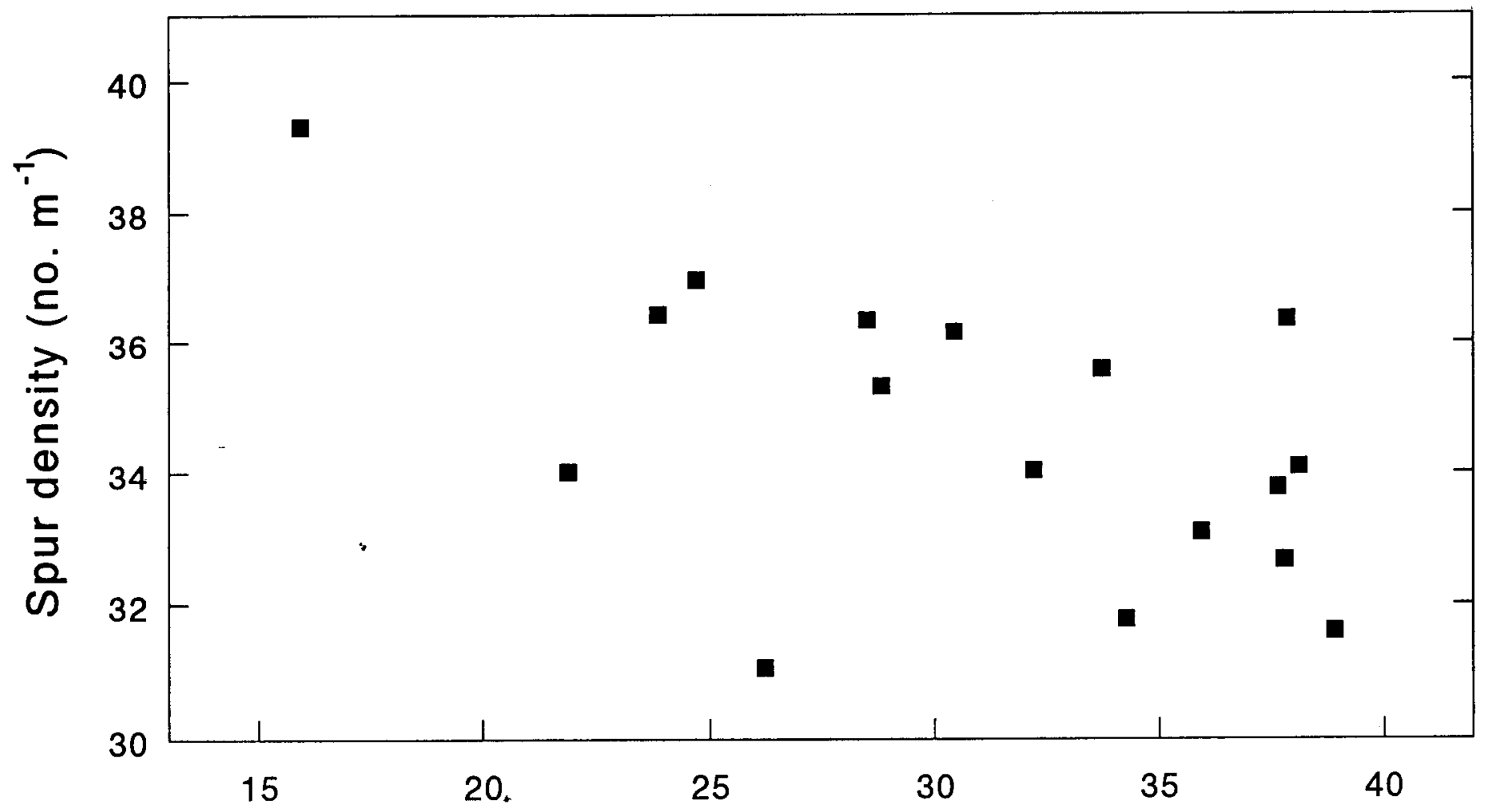

\section{Shoot length $(\mathrm{cm})$}

Fig. 3. Plot of spur density and the length of the 2-yem-old branch section for 'Starkspur Supreme Delicious' trees growing on 17 rootstock measured over 6 years (n $=300), r=0.55, P \leq 0.05$. 


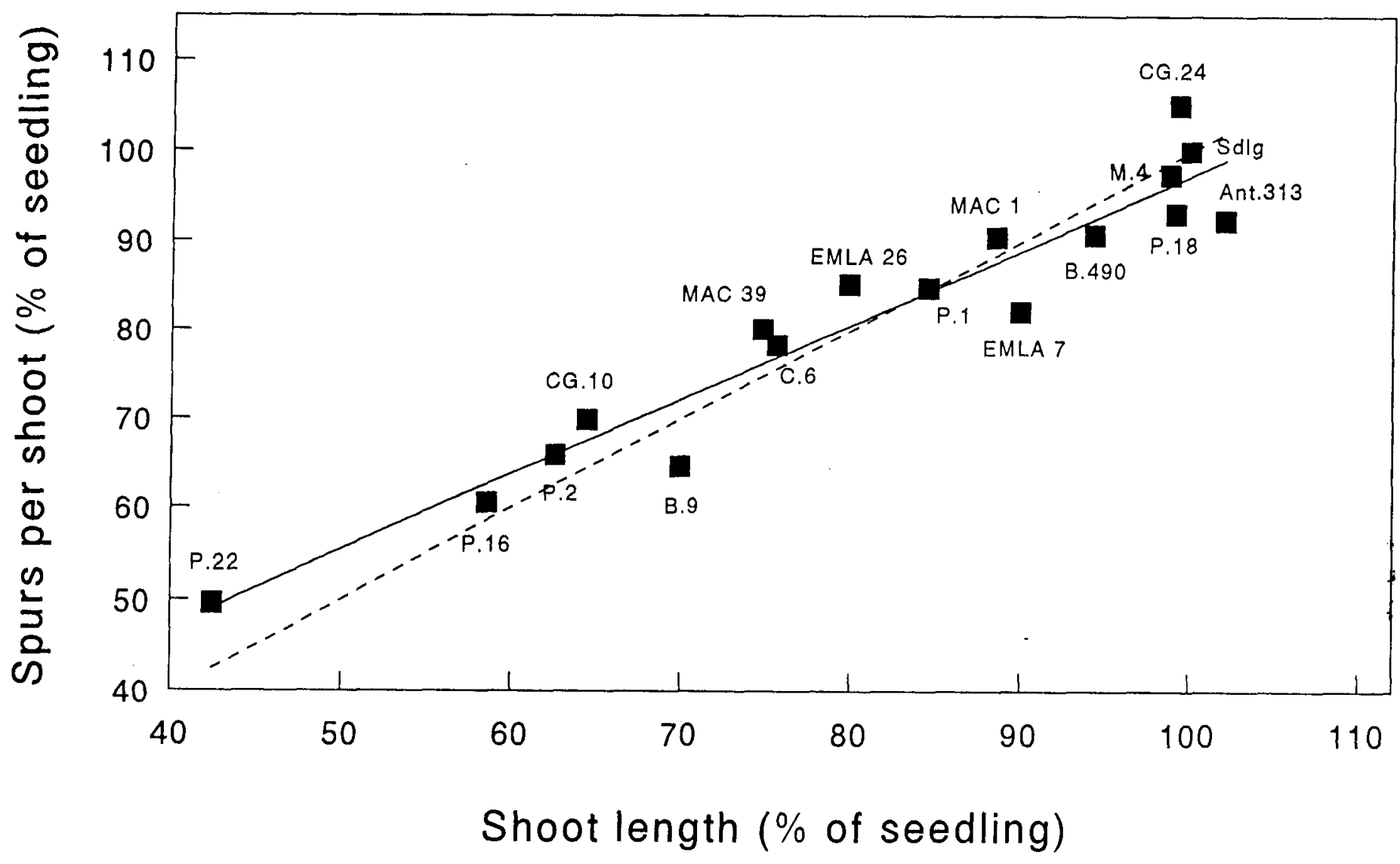

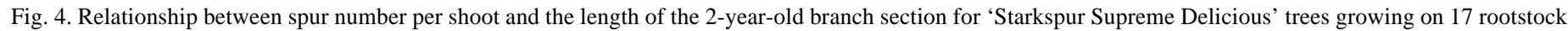
and measured over 6 years $(\mathrm{n}=300)$. The mean spur number and shoot length for each rootstock are expressed as a percentage of the mean for trees growing on seedling rootstock. Solid line is line of best fit $\left(\mathrm{y}=0.837 \mathrm{x}+13.5, r^{2}=0.92, P \leq 0.001\right)$. Dashed line represents points where spur numbers and shoot length are an equal percentage of seedling. Rootstock above this line have higher mean spur densities than seedling and those below the line have lower spur densities than seedling.

leaf area per spur both increased with increasing tree size. Trends similar to those described for TCSA were evident with the length of the shoot, where leaf area per spur and spur leaf size increased in proportion to shoot length and leaf number per spur and SLW were higher in trees with shorter shoots (Table 5). Overall, leaf area per spur was related positively with individual leaf size $\left(r^{2}=0.65\right.$, $P \leq 0.001)$ but not with leaf number per spur, and leaf dry weight per spur was dependent on leaf area per spur $\left(r^{2}=0.80, P \leq 0.001\right)$ and not SLW. A weak positive relationship between terminal bud diameter and leaf dry weight was evident $(r=0.52, \boldsymbol{P}<0.05)$, but terminal bud diameter was not related to other spur leaf characteristics (data not shown). In general, more vigorous trees had larger spur leaves and more leaf area per spur, but fewer spur leaves on each spur with lower SLW.

Precocity and productivity. Small yields were borne by some trees in 1986 and all trees in 1987, but it was not until 1988 that significant yields were carried (Table 6). The yield efficiency (kg crop $/ \mathrm{m}^{2} \mathrm{TCSA}$ ) of trees on all rootstock increased rapidly from 1986-88, after which a plateau was attained (Table 7). Yield per tree increased with increasing tree size, but the efficiency of production (yield/TCSA) decreased (Table 8). The length of the 2year-old branch section was correlated positively with the yield per tree each year from 1988-93 and was related negatively to yield efficiency in 3 of the 6 years. Spur density was related negatively with yield per tree in 1989 but associated positively with yield efficiency in 1988 and 1990. Flower density was related to yield per tree and yield efficiency only in 1 of 2 years, respectively, while the proportion of spurs that flowered generally was not a good indicator of the level of cropping (Table 8). Generally, characteristics associated with increased vigor (increased TCSA, shoot length, and spur number) resulted in higher yields per tree but lower yield efficiencies.

An index of precocity was derived by expressing the early yield (1984-88) on a TCSA basis, whereas productivity was defined as the cumulative yield (1984-93) also on a TCSA basis. Tree vigor as affected by rootstock (estimated by shoot length or TCSA) was closely related to precocity and productivity, where rootstock with shorter shoot lengths and smaller TCSA were more precocious and more productive than more vigorous rootstock (Tables 8 and 9). Increased spur density tended to be associated with higher precocity and productivity, but the relationships were not significant. More highly precocious and productive trees had more spur leaves per spur and higher spur SLW, but their spur leaves were smaller (Table 5). Precocity was a good predictor of longer-term productivity $\left(r^{2}=0.91, P \leq 0.001\right)$, where trees on P.22 and P. 16 rootstock were the most precocious and most productive and trees on B.490 and seedling rootstock the least.

\section{Discussion}

Considerable yearly variation was exhibited by many of the variables used to measure shoot morphology in this study. For shoot length, spur density, and flower number, $67 \%-80 \%$ of the total yearly variation could be attributed to differences in 1988 compared with 1989-93. The 2-year-old branch sections measured in 1988 grew during 1986 and spurs and flowers developed 

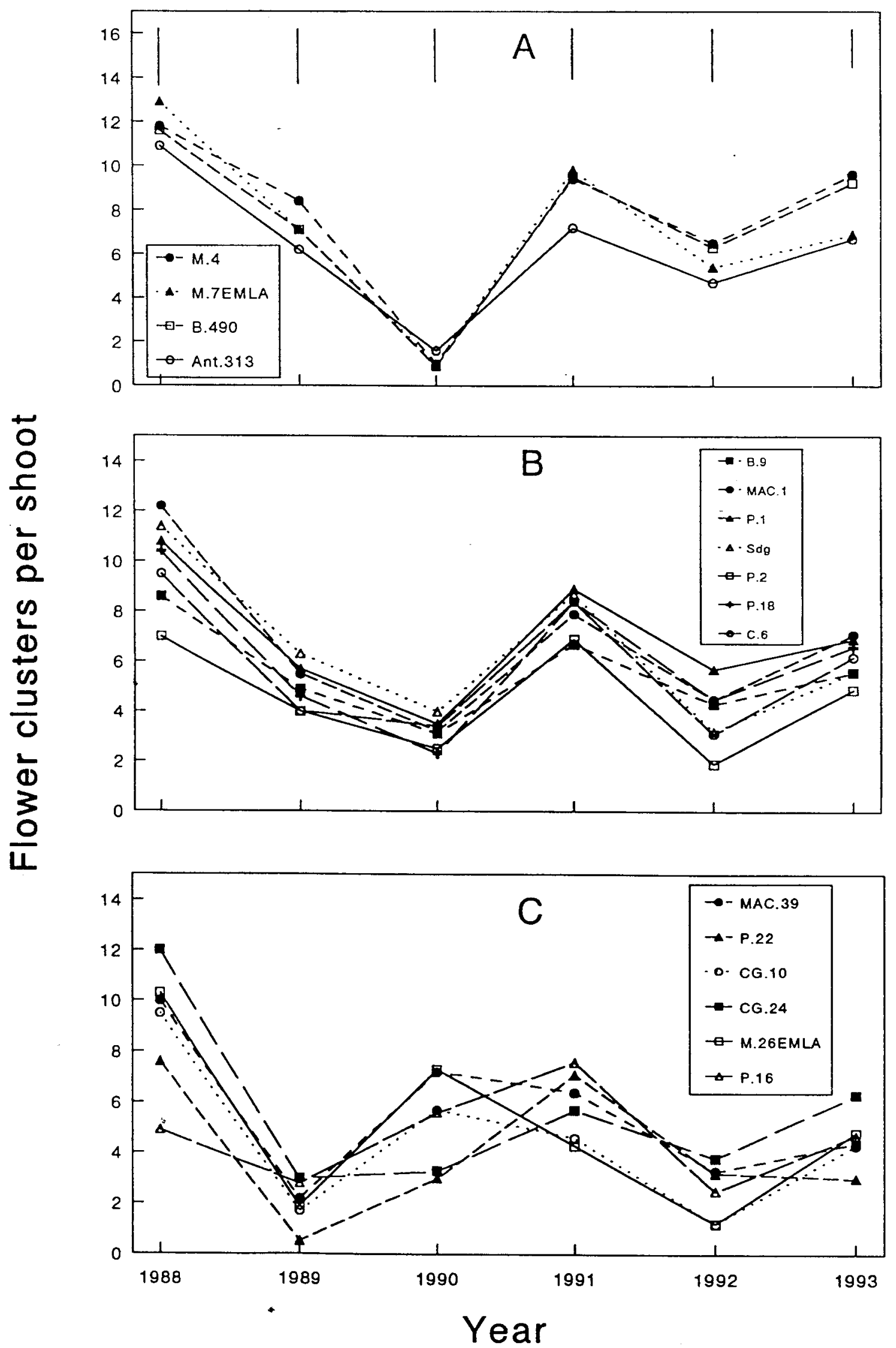

Fig. 5. The effect of rootstock and year on the number of flower clusters on the 2-year-old branch section of 'Starkspur Supreme Delicious' trees growing on 17 rootstock $(\mathrm{n}=50)$. A, B, and $\mathbf{C}$ represent different groups of rootstock separated on the basis of the pattern of their response to year. Bars indicate LSD $P=0.05$. 


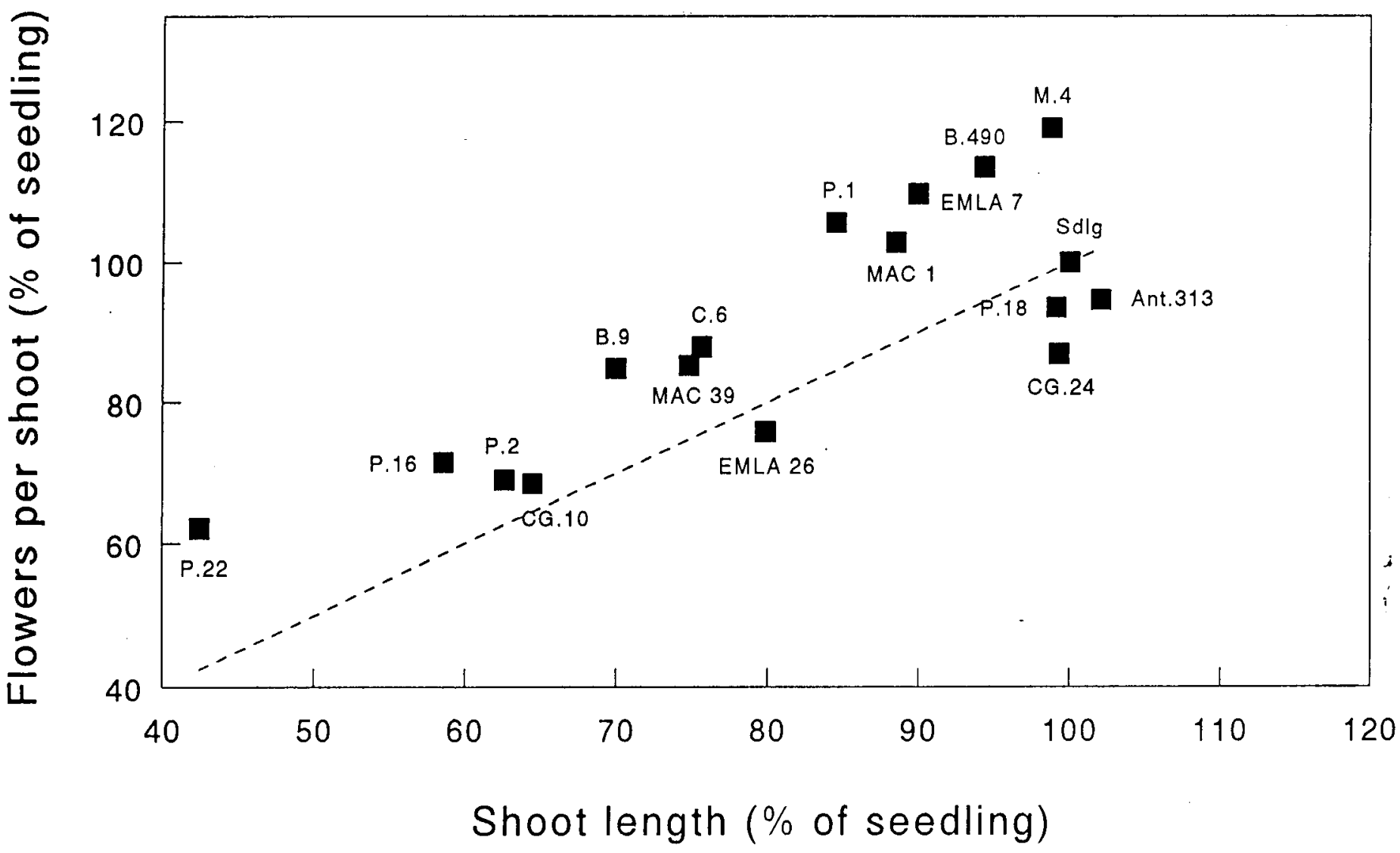

Fig. 6. Relationship between the length of the 2-year-old branch section and the number of flower clusters borne on that section for 'Starkspur Supreme Delicious' trees growing on 17 rootstock and measured over 6 years $(n=300)$. The mean flower number and shoot length for each rootstock are expressed as a percentage of the mean for trees growing on seedling rootstock, Dashed line represents points where flower number and shoot length are an equal percentage of seedling. Rootstock above this line have higher mean flower densities than seedling and those below the line have lower flower densities than seedling.

on these branches in 1987 . The time at which most of the yearly differences occurred coincided with the period of first fruiting of the trees, with a rapid increase in cropping from 1986-88. Cropping may explain these differences since fruiting is associated with decreased shoot growth (Avery, 1970), and in this study shoot growth was related to many of the shoot morphology variables studied.

The separation of rootstock into groups depending on their pattern of response to year for spur number per shoot and flower number per shoot generally was not related to the degree of size control exerted on the tree by the rootstock, with individual groups including dwarfing and vigorous rootstock. Spur numbers per shoot were relatively stable among years and differences among groups of rootstock were largely in the degree of their response to year rather than qualitative differences in the response. With flower number, however, marked differences among groups of rootstock were evident, mainly in 1989 and 1990. Flowering in 1989 was related to the yield efficiency in the previous year, where trees with heavier crops in 1988 generally produced fewer flowers in 1989.

During the period of study, years of extreme temperatures and rainfall were experienced (Table 10). Total rainfall from AprilOctober ranged from $63 \%$ of the long-term average in 1991 to $122 \%$ in 1990 . However, flowers are initiated and most of the vegetative growth occurs from April to July. During this period, the rainfall in 1991 was only $57 \%$ of that in an average year, while in 1990 it was $106 \%$. Temperatures were similarly variable, with the mean monthly temperature from April-July in $19912.4 \mathrm{C}$ above normal, and over the same period in $19900.2 \mathrm{C}$ below the long-term average (data not presented). It is interesting to note that, despite years of extreme temperature and rainfall over the period of study, most of the yearly variation could be ascribed to cropping characteristics rather than to environmental variables. However, the severe drought experienced in 1991 appears to have resulted in reduced flowering and shoot growth (measured in 1992 and 1993, respectively).

TCSA has long been used as a predictor of above-ground tree fresh weight and tree size (Westwood and Roberts, 1970; Wilcox, 1937). In the present study, TCSA was a good indicator of individual shoot length within a given year, explaining 64\%-90\% of the variation depending on year. Individual shoot lengths are only one contributor to total above ground tree weight, which is also comprised of shoot number per tree, previous years extension growth, and secondary thickening of structural wood. As trees age, several phenomena occur to alter the relationship between shoot growth and TCSA. The previous year's extension growth and secondary thickening or structural components become a proportionately greater part of the tree, and carbohydrates are partitioned into fruit, thus reducing the number of shoots and individual shoot length (Avery, 1970). Tree age influences on the relationship between TCSA and shoot length were evident in this study, where changes in individual shoot length had a much greater effect on TCSA in the third growing season compared with the 8th year, with slopes of 1.86 and 0.10 , respectively. Over all years, the largest rootstock had about twice the shoot length as the smallest, whereas the difference in TCSA was about 10-fold. This discrepancy 


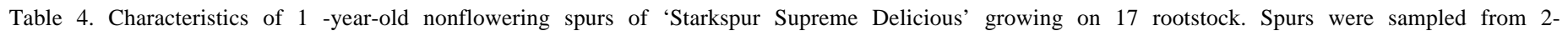
year-old wood on 17 Sept. 1991.

\begin{tabular}{|c|c|c|c|c|c|c|}
\hline Rootstock & $\begin{array}{c}\text { Leaf } \\
\text { no. }\end{array}$ & $\begin{array}{c}\text { Leaf } \\
\text { area } \\
\left(\mathrm{cm}^{2}\right)\end{array}$ & $\begin{array}{c}\text { Leaf } \\
\text { size } \\
\left(\mathrm{cm}^{2}\right)\end{array}$ & $\begin{array}{c}\text { Bud } \\
\text { diam } \\
(\mathrm{mm})\end{array}$ & $\begin{array}{c}\text { Dry } \\
\text { wt } \\
\text { (g/spur) }\end{array}$ & $\begin{array}{c}\text { Specific } \\
\text { leaf wt } \\
\left(\mathrm{mg} \cdot \mathrm{cm}^{-2}\right)\end{array}$ \\
\hline P.22 & 6.8 & 57.42 & 8.52 & 3.38 & 3.37 & 11.70 \\
\hline P. 16 & 7.2 & 65.94 & 9.20 & 3.38 & 4.00 & 12.14 \\
\hline P. 2 & 6.6 & 64.64 & 9.90 & 3.40 & 3.89 & 12.02 \\
\hline CG. 10 & 6.9 & 51.32 & 7.46 & 3.12 & 3.00 & 11.66 \\
\hline B.9 & 6.5 & 57.58 & 8.90 & 3.52 & 3.52 & 12.18 \\
\hline MAC.39 & 7.1 & 61.28 & 8.64 & 3.58 & 3.67 & 11.98 \\
\hline M.26EMLA & 6.7 & 67.22 & 10.04 & 3.40 & 3.95 & 11.74 \\
\hline C. 6 & 6.8 & 60.06 & 8.82 & 3.52 & 3.71 & 12.38 \\
\hline P. 1 & 6.2 & 64.06 & 10.24 & 3.52 & 3.75 & 11.68 \\
\hline M.7EMLA & 6.5 & 67.48 & 10.36 & 3.50 & 3.90 & 11.58 \\
\hline M.4 & 5.8 & 59.86 & 10.24 & 3.30 & 3.26 & 10.86 \\
\hline MAC. 1 & 6.8 & 69.04 & 10.20 & 3.54 & 3.87 & 11.16 \\
\hline CG. 24 & 6.7 & 73.14 & 10.84 & 3.34 & 3.99 & 10.92 \\
\hline B. 490 & 6.7 & 61.20 & 9.52 & 3.24 & 3.40 & 11.08 \\
\hline P. 18 & 6.9 & 72.76 & 10.58 & 3.28 & 4.11 & 11.26 \\
\hline Ant. 313 & 6.2 & 67.96 & 11.06 & 3.38 & 3.96 & 11.64 \\
\hline Seedling & 5.8 & 64.32 & 11.02 & 3.28 & 3.54 & 11.00 \\
\hline $\operatorname{LSD}(P=0.05)$ & 0.9 & 11.46 & 1.28 & 0.28 & 0.70 & 0.54 \\
\hline
\end{tabular}

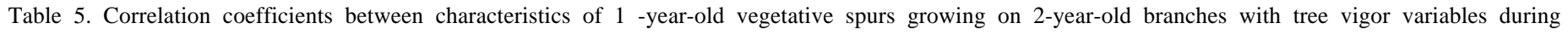
the year of shoot growth (1989) and the year of bud development ( 1990), precocity, and productivity.

\begin{tabular}{|c|c|c|c|c|c|c|}
\hline \multirow{2}{*}{$\begin{array}{l}\text { Spur } \\
\text { characteristics }^{2}\end{array}$} & \multicolumn{2}{|c|}{ TCSA } & \multicolumn{2}{|c|}{$\begin{array}{l}\text { Shoot } \\
\text { length }\end{array}$} & \multirow[b]{2}{*}{ Precocity $^{w}$} & \multirow[b]{2}{*}{ Productivity $^{v}$} \\
\hline & $1989^{y}$ & $1990 *$ & $1991^{y}$ & 1992 & & \\
\hline Leaves/spur & $-0.52 *$ & $-0.55^{*}$ & $-0.51 *$ & $-0.62 * *$ & $0.57 *$ & $0.57 *$ \\
\hline Leaf area/spur & $0.55^{*}$ & $0.56^{*}$ & $0.53^{*}$ & 0.48 & -0.48 & 4.40 \\
\hline Leaf area/leaf & $0.76^{* * *}$ & $0.78 * * *$ & $0.72 * * *$ & $0.69 * *$ & $4.71 * * *$ & $4.66 * *$ \\
\hline Bud diameter & -0.14 & -0.15 & -0.08 & -0.11 & 0.12 & 0.22 \\
\hline Leaf dry weight & 0.22 & 0.23 & 0.34 & 0.19 & -0.16 & -0.17 \\
\hline Specific leaf weight & $-0.70 * *$ & $-0.73 * * *$ & $-0.63 * *$ & $-0.64 * *$ & $0.67 * *$ & $0.74 * * *$ \\
\hline
\end{tabular}

${ }^{2}$ Measured in 1991.

${ }^{y}$ Year of shoot growth.

${ }^{x}$ Year of bud development.

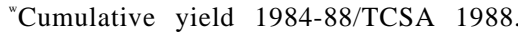

"Cumulative yield 1984-93/TCSA 1993.

$*$, **, ***Significant at $P \leq 0.05,0.01$, or 0.001 , respectively.

suggests a large difference in the number of shoots per tree and the amount of photosynthates directed into fruit and tree structure and warns against the use of shoot length as a sole indicator of tree vigor.

Spur density was influenced by rootstock, but the range of values was small. Measuring strain and rootstock effects on vegetative spur characteristics, Warrington et al. (1990) observed much greater differences in spur density among 'Delicious' strains than among trees of one strain growing on a range of rootstock. From a study with young trees, Hirst and Ferree (1994) concluded that total growth was under rootstock control,but the distribution of growth was mainly controlled by cultivar. In the present study, spur density was not related to spur characteristics or to yield variables, which suggests that the way in which rootstock control productivity is not by changes in the number of potential fruitbearing sites (spurs).

Rootstock had relatively little effect on flower density, since most of the variation in flower number per shoot could be explained by shoot length and no significant effect of flower density on flower number was observed (Table 3 ). Flower density generally was higher on smaller trees with shorter shoots, but these relationships were weak, leaving $70 \%$ of the variation in flower density unexplained. Primarily, flower density was not due to the presence of longer shoots or more spurs, rather that more spurs formed flowers (Table 3 ). The strong influence of the proportion of spurs forming flowers on flower density and the weak relationship between shoot length and flower density suggest that rootstock influences on flowering are due to other more direct control mechanisms on individual buds.

Rootstock appeared to fall into two groups based on their flower densities. Trees on seedling, Ant. 313, P. 18, CG.24, and M.26EMLA had flower densities below 18 clusters $/ \mathrm{m}$, whereas, trees on other rootstock generally had in excess of 20 clusters $/ \mathrm{m}$. Despite its low flower density M.26EMLA had relatively high 
Table 6. Yield/tree (kg) of 'Starkspur Supreme Delicious' trees planted in 1984 and grown on 17 rootstock.

\begin{tabular}{|c|c|c|c|c|c|c|c|c|}
\hline Rootstock & 1986 & 1987 & 1988 & 1989 & 1990 & 1991 & 1992 & 1993 \\
\hline P.22 & 0.22 & 5.0 & 17.0 & 7.0 & 11.2 & 14.0 & 10.2 & 7.8 \\
\hline P.16 & 0.18 & 6.2 & 16.2 & 18.8 & 21.2 & 19.8 & 15.8 & 19.8 \\
\hline P. 2 & 0.42 & 6.6 & 25.0 & 27.4 & 34.6 & 30.2 & 28.0 & 33.3 \\
\hline CG.10 & 0.13 & 8.7 & 27.1 & 17.5 & 37.5 & 27.6 & 21.1 & 41.9 \\
\hline B.9 & 0.02 & 8.6 & 27.1 & 27.3 & 30.2 & 27.7 & 44.7 & 52.3 \\
\hline MAC.39 & 0.67 & 11.8 & 31.9 & 24.4 & 56.0 & 40.6 & 41.8 & 66.0 \\
\hline M.26EMLA & 0.72 & 12.1 & 40.7 & 37.5 & 66.8 & 59.7 & 49.4 & 81.3 \\
\hline C. 6 & 0.18 & 14.9 & 29.8 & 33.6 & 57.6 & 48.4 & 53.8 & 82.9 \\
\hline P. 1 & 0.14 & 9.5 & 38.6 & 52.8 & 49.3 & 56.1 & 62.7 & 98.7 \\
\hline M.7EMLA & 0.37 & 7.0 & 34.6 & 58.1 & 29.5 & 50.7 & 82.8 & 105.9 \\
\hline M.4 & 0.53 & 5.3 & 35.3 & 55.1 & 32.2 & 52.0 & 77.9 & 101.7 \\
\hline MAC.1 & 0.07 & 6.6 & 35.8 & 46.2 & 58.4 & 50.4 & 64.1 & 94.5 \\
\hline CG.24 & 0.04 & 4.5 & 27.6 & 51.1 & 44.6 & 56.5 & 58.1 & 98.7 \\
\hline B. 490 & 0.26 & 3.2 & 27.7 & 46.0 & 29.2 & 39.7 & 67.2 & 89.1 \\
\hline P.18 & 0.50 & 4.1 & 35.7 & 55.4 & 50.0 & 57.8 & 80.1 & 102.6 \\
\hline Ant. 313 & 0.43 & 4.3 & 53.9 & 48.8 & 40.6 & 50.3 & 77.5 & 108.3 \\
\hline Seedling & 0.42 & 7.8 & 25.2 & 53.3 & 47.8 & 46.2 & 83.1 & 106.4 \\
\hline LSD $(\mathrm{P} \leq 0.05)$ & 0.52 & 4.6 & 17.2 & 14.3 & 16.2 & 13.5 & 16.3 & 17.6 \\
\hline
\end{tabular}

Table 7. Yield efficiency ( $\mathrm{kg}$ crop/cm ${ }^{2}$ TCSA) of 'Starkspur Supreme Delicious' trees planted in 1984 and grown on 17 rootstock.

\begin{tabular}{|c|c|c|c|c|c|c|c|c|}
\hline Rootstock & 1986 & 1987 & 1988 & 1989 & 1990 & 1991 & 1992 & 1993 \\
\hline P.22 & 0.04 & 0.58 & 2.05 & 0.66 & 0.97 & 1.12 & 0.67 & 0.52 \\
\hline P.16 & 0.02 & 0.71 & 1.14 & 1.28 & 1.03 & 0.93 & 0.76 & 1.02 \\
\hline P. 2 & 0.08 & 0.54 & 1.29 & 1.15 & 1.21 & 0.91 & 0.73 & 1.03 \\
\hline CG.10 & 0.01 & 0.53 & 1.38 & 0.78 & 1.34 & 0.87 & 0.61 & 1.05 \\
\hline B. 9 & 0 & 0.45 & 1.19 & 0.92 & 0.93 & 0.74 & 0.94 & 1.06 \\
\hline MAC.39 & 0 & 0.59 & 1.24 & 0.74 & 1.41 & 0.91 & 0.78 & 1.16 \\
\hline M.26EMLA & 0.03 & 0.42 & 1.14 & 0.80 & 1.17 & 0.94 & 0.66 & 1.01 \\
\hline C. 6 & 0.01 & 0.52 & 0.83 & 0.72 & 1.09 & 0.81 & 0.78 & 0.98 \\
\hline P. 1 & 0.01 & 0.27 & 0.90 & 0.95 & 0.72 & 0.69 & 0.73 & 0.94 \\
\hline M.7EMLA & 0.02 & 0.18 & 0.75 & 1.08 & 0.39 & 0.60 & 0.87 & 1.01 \\
\hline M.4 & 0.03 & 0.14 & 0.77 & 1.03 & 0.39 & 0.56 & 0.73 & 0.85 \\
\hline MAC.1 & 0 & 0.16 & 0.65 & 0.69 & 0.64 & 0.49 & 0.53 & 0.70 \\
\hline CG.24 & 0 & 0.12 & 0.54 & 0.74 & 0.50 & 0.53 & 0.47 & 0.72 \\
\hline B. 490 & 0.01 & 0.07 & 0.46 & 0.64 & 0.30 & 0.35 & 0.52 & 0.60 \\
\hline P.18 & 0.02 & 0.06 & 0.64 & 0.79 & 0.48 & 0.48 & 0.58 & 0.66 \\
\hline Ant. 313 & 0.03 & 0.10 & 0.93 & 0.69 & 0.40 & 0.43 & 0.57 & 0.70 \\
\hline Seedling & 0.01 & 0.21 & 0.38 & 0.64 & 0.43 & 0.36 & 0.55 & 0.64 \\
\hline $\operatorname{LSD}(P \leq 0.05)$ & 0.04 & 0.23 & 0.50 & 0.45 & 0.26 & 0.21 & 0.21 & 0.15 \\
\hline
\end{tabular}

Table 8. Correlation coefficients between various indices of precocity and productivity and shoot morphology variables and tree size for 'Starkspur Supreme Delicious' trees grown on 17 rootstock over 6 years.

\begin{tabular}{|c|c|c|c|c|c|c|c|c|c|c|c|c|c|c|}
\hline \multirow[b]{2}{*}{ Characteristic } & \multicolumn{6}{|c|}{ Yield/tree (kg) } & \multicolumn{6}{|c|}{ Yield efficiency $\left(\mathrm{kg} \cdot \mathrm{cm}^{2}\right)$} & \multirow[b]{2}{*}{ Precocity $^{2}$} & \multirow[b]{2}{*}{ Productivity ${ }^{y}$} \\
\hline & 1988 & 1989 & 1990 & 1991 & 1992 & 1993 & 1988 & 1989 & 1990 & 1991 & 1992 & 1993 & & \\
\hline Shoot length & $0.62^{* *}$ & $0.87^{* * *}$ & $0.62^{* *}$ & $0.80^{* * *}$ & $0.86^{* * *}$ & $0.79^{+* *}$ & $-0.86^{* * *}$ & -0.29 & $-0.59^{*}$ & $-0.86^{* * *}$ & -0.46 & -0.26 & $-0.93^{* * *}$ & $-0.91^{* * *}$ \\
\hline Spur number & 0.46 & $0.68^{* *}$ & $0.67^{* *}$ & $0.75^{* * *}$ & $0.74^{* * *}$ & $0.80^{* * *}$ & $-0.78^{* * *}$ & -0.39 & $-0.52^{*}$ & $-0.78^{* * *}$ & $-0.58^{*}$ & -0.30 & $-0.91^{* * *}$ & $-0.88^{* * *}$ \\
\hline Spur density & -0.43 & $-0.66^{* *}$ & -0.22 & -0.36 & -0.24 & -0.18 & $0.50^{*}$ & -0.16 & 0.43 & $0.58^{*}$ & -0.45 & -0.14 & 0.46 & 0.42 \\
\hline Flower number & $0.58^{*}$ & $0.79^{* * *}$ & 0.42 & 0.18 & $0.66^{* *}$ & $0.71^{* * *}$ & $-0.74^{* * *}$ & 0 & $0.77^{* * *}$ & -0.45 & -0.10 & -0.22 & $-0.85^{* * *}$ & $-0.76^{* * *}$ \\
\hline Flower density & -0.28 & $0.61^{* *}$ & 0.12 & -0.46 & 0.19 & 0.22 & $0.69^{* *}$ & 0.21 & $0.89^{\ldots * *}$ & 0.27 & 0.15 & -0.05 & $0.58^{*}$ & 0.40 \\
\hline Flower spur (\%) & $\cdots$ & -- & 0.16 & -0.31 & 0.23 & 0.33 & --- & $\cdots$ & $0.88^{*+* *}$ & 0 . & 0.26 & 0.12 & --- & $0.51^{*}$ \\
\hline TCSA & $0.55^{*}$ & $0.89^{* * *}$ & 0.41 & $0.77^{* * *}$ & $0.91^{* * *}$ & $0.92^{* * *}$ & $-0.92^{* * *}$ & $-0.52^{*}$ & $-0.85^{* * *}$ & $-0.95^{* * *}$ & $-0.64^{* *}$ & $-0.53^{*}$ & $-0.96^{* * *}$ & $-0.97^{* * *}$; \\
\hline
\end{tabular}

${ }^{2}$ Cumulative yield 1984-88/TCSA 1988, correlated against shoot morphology characteristics measured in 1988.

${ }^{y}$ Cumulative yield 1984-93/TCSA 1993, correlated against mean of shoot morphology variables 1988-93.

$*, * *, * * *$ Significant at $P, 0.05,0.01$, or 0.001 , respectively. 
precocity and productivity indices, suggesting a high degree of fruit set. Trees of 'Golden Delicious' growing on M.9 rootstock retained more fruit with fewer seeds than other rootstock, but trees on M.26 performed similarly to those on M.7 and MM. 106 rootstock (Blasco et al., 1982); therefore, the retention of fruit with fewer seeds does not appear to be the mechanism by which M.26 achieved a high degree of fruit set.

Highest degrees of lateral branching occurred during the years in which the longest shoot lengths were recorded and the trees were relatively young. Increased lateral branching on more vigorous trees has been reported previously (Hirst and Ferree, 1994), and, in the present study, decreased lateral branching was associated with the time of first production from these trees. The number of growing points per meter was constant over this period; therefore, reductions in lateral branches were accompanied by increases in spur density. From these data it seems possible that the presence of fruit led to spur production in favor of lateral shoots, perhaps by a reduction of vigor brought about by re-allocation of carbohydrates to fruit. It is equally plausible that a shift in the ratio of spurs to lateral shoots may have resulted in a lowering of the level of gibberellins from shoot tips that are inhibitory to flowering. Gibberellin levels have been associated with branching in

Table 9. Precocity and productivity of 'Starkspur Supreme Delicious' trees growing on 17 rootstock.

\begin{tabular}{lcc}
\hline \hline Rootstock & Precocity $^{\mathrm{z}}$ & Productivity $^{\mathrm{y}}$ \\
\hline P.22 & 2.64 & 5.01 \\
P.16 & 1.74 & 4.95 \\
P.2 & 1.89 & 5.09 \\
CG.10 & 1.85 & 4.62 \\
B.9 & 1.61 & 4.47 \\
MAC.39 & 1.71 & 4.70 \\
M.26EMLA & 1.50 & 4.33 \\
C.6 & 1.27 & 4.05 \\
P.1 & 1.13 & 3.79 \\
M.7EMLA & 0.91 & 3.51 \\
M.4 & 0.89 & 2.94 \\
MAC. 1 & 0.78 & 2.63 \\
CG.24 & 0.63 & 2.48 \\
B.490 & 0.52 & 2.05 \\
P.18 & 0.70 & 2.46 \\
Ant.313 & 1.01 & 2.48 \\
Seedling & 0.50 & 2.21 \\
LSD (P = 0.05) & 0.58 & 0.63 \\
\hline
\end{tabular}

${ }^{\overline{2}}$ Precocity = yield/tree 1984-88/TCSA 1988.

'Productivity = yield/tree 1984-93/TCSA 1993.

Table 10. Accumulated rainfall from Auri-October in Wooster, Ohio. nonbranching mutants of 'McIntosh' apple ('McIntosh Wijick' ), which had much lower levels of polar gibberellins in shoot tips than strains exhibiting greater degrees of branching (Looney et al., 1988). Alternatively, increased flower and fruit production may have resulted from some factor reducing the outgrowth of spurs into lateral shoots,

The range of values observed for each of the spur quality variables was similar to that found by Warrington et al. (1990), who worked with the same cultivar but a different range of rootstock. Although dwarfing rootstock had more spur leaves than vigorous rootstock, the leaves were smaller resulting in less leaf area per spur. The higher spur SLW of trees on more dwarfing rootstock has been reported previously (Warrington, 1990) and may compensate, in terms of total photosynthetic potential, for lower leaf area. Higher spur SLW in smaller trees may have resulted from improved light distribution within the smaller canopies, since SLW is related to canopy light levels (Barritt et al., 1987).

Relationships between tree vigor and spur characteristics may be affected by yearly growing conditions since relationships between tree size and leaf number per spur, leaf area per spur, and leaf size were found among rootstock by Warrington et al. (1990), but no relationships were detected in another study (Rottgerman et al., 1994). It is unlikely that these discrepancies are attributable to cultivar or soil type since these studies were conducted with the same scion cultivar on sites close to one another. Possibly, yearly variation in spur characteristics argues against the use of such characteristics of a common scion as universal indices of potential rootstock vigor in rootstock breeding research. Further research is required to assess the stability of the relationships with vigor across years.

Among cultivars, spur leaf characteristics, particularly spur leaf area, were closely related with accumulated yields (Rem and Ferree, 1984). In this study, spur leaf area was not related to longterm productivity among rootstock, but leaf number per spur, spur leaf size, and spur SLW were correlated with precocity and productivity. When combined, these three spur quality attributes accounted for $62 \%$ and $65 \%$ of the variation in precocity and productivity, respectively.

In this study, the best predictor of precocity and productivity was scion vigor, as estimated by either shoot length or TCSA (Table 8). Since increases in TCSA over time were linear for all rootstock, the total productivity over 10 years could be reliably predicted as early as the 3rd or 4th year using TCSA $\left(r^{2}=0.85, P\right.$ $\leq 0.001$ and $r^{2}=0.94, P \leq 0.001$, respectively). Early work by Preston (1958) suggested that the relative order of rootstock for cropping was not established until the 20th year, but, in later work with improved cultural practices, the relative order could be

\begin{tabular}{|c|c|c|c|c|c|c|c|c|}
\hline \multirow[b]{2}{*}{ Month } & \multicolumn{8}{|c|}{ Accumulated rainfall $(\mathrm{mm})^{2}$} \\
\hline & 1986 & 1987 & 1988 & 1989 & 1990 & 1991 & 1992 & $\begin{array}{l}\text { Long-term } \\
\text { average }^{y}\end{array}$ \\
\hline April & 53 & 58 & 56 & 45 & 64 & 77 & 57 & 84 \\
\hline May & 132 & 117 & 88 & 160 & 189 & 159 & 109 & 184 \\
\hline June & 270 & 243 & 101 & 342 & 251 & 201 & 163 & 285 \\
\hline July & 371 & 321 & 263 & 385 & 415 & 223 & 374 & 391 \\
\hline August & 405 & 439 & 349 & 408 & 529 & 301 & 476 & 485 \\
\hline September & 501 & 494 & 423 & 520 & 644 & 368 & 563 & 565 \\
\hline October & 589 & 533 & 459 & 585 & 761 & 395 & 608 & 625 \\
\hline
\end{tabular}

${ }^{\bar{z}}$ Accumulated from 1 Apr.

${ }^{y}$ Mean of $>90$ years. 
determined after 7 years for rootstocks smaller in size than M.7 and 15 years for those larger than M.7 (Preston, 1967). The finding of the present study that the productivity of rootstock covering a wide range of tree size could be predicted in the 3rd or 4th year, offers the potential to provide an early screening technique in rootstock breeding and evaluation research.

\section{Literature Cited}

Avery, D.J. 1970. Effects of fruiting on the growth of apple trees on four rootstock varieties. New Phytol. 69: 19-30.

Barritt, B. H., C.R. Rem, K.R. Guelich, S.R. Drake, and M.A. Dilley. 1987. Canopy position and light effects on spur, leaf, and fruit characteristics of 'Delicious' apple. HortScience 22:402-405.

Blasco, A. B., S.M. El Senfaz, and J.E. Jackson. 1982. The effects of rootstock on the response of Cox's Orange Pippen apple to fruit-setting hormone sprays. J. Hort. Sci. 57(3):267-275.

Ferree, D.C. 1989. Influence of orchard management systems on spur quality, light, and fruit within the canopy of Golden Delicious apple trees. J. Amer. Soc. Hort. Sci. 114:869-875.

Ferree, D.C. and R.F. Carlson. 1987. Apple rootstock, p. 107-144. In: R.C. Rom and R.F. Carlson (eds.). Rootstock for fruit crops. Wiley, New York.

Forshey, C.G. and M.W. McKee. 1970. Production efficiency of a large and a small 'McIntosh' apple tree. HortScience 5:164-165.

Heinicke, D.R. 1964. The micro-climate of fruit trees. III. The effect of tree size on light penetration and leaf area in Red Delicious apple trees. Proc. Amer. Soc. Hort. Sci. 85:33-41.

Hirst, P.M. and D.C. Ferree. 1995. Effect of rootstock and cultivar on the growth and precocity of young apple trees. Fruit Var. J. 49(1):3441.

Jackson, J.E. 1980. Light interception and utilization by orchard systems. Hort. Rev. 2:208-267.

Ketchie, D.O. 1984. Flowering, spur formation and limb angles of Delicious apple strains. Fruit Var. J. 38:15\&152.
Looney, N. E., J.S. Taylor, and R.P. Pharis. 1988. Relationship of endogenous gibberellin and cytokinin levels in shoot tips to apical form in four strains of 'McIntosh' apple. J. Amer. Soc. Hort. Sci. 113:395-398.

Minitab. 1993. Minitab reference manual, release 9 for Windows. Minitab, State College, Pa.

NC- 140.1990. Early performance of 'Starkspur Supreme Delicious' on 16rootstocks in the NC-140 Cooperative planting. Fruit Var. J. 44(4):225235.

Preston, A.P. 1958. Apple rootstock studies: Thirty-five years' results with Lane's Prince Albert on clonal rootstock. J. Hort. Sci. 33(1):29_ 38.

Preston, A.P. 1967. Apple rootstock studies: Fifteen years' results with some M.IX crosses. J. Hort. Sci. 42:41-50.

Preston, A.P. 1968. Scion weight and cropping of Cox's Orange Pippin and Jonathan apples on some Mailing and Mailing-Merton rootstock. Rpt. E. Mailing Res. Sta. 1967:98-102.

Rem, C.R. and D.C. Ferree. 1984. Spur leaf characteristics of nine apple cultivars. Fruit Var. J. 38(1):2-5.

Rottgerman, M., D. Ferree, and J. Schmid. 1994. Rootstock effects on spur characteristics, spur leaf nitrogen content and early production of apple trees. Fruit crops: A summary of research. OARDC. Res. Circ. p. 43-50.

SAS Institute. 1989. SAS/STAT user's guide. version 6. 4th ed. SAS Institute, Cary, NC.

Warrington, I.J., D.C. Ferree, J.R. Schupp, F.G. Dennis, and T.A. Baugher. 1990. Strain and rootstock effects on spur characteristics and yield of 'Delicious' apple strains. J. Amer. Soc. Hort. Sci. 115:348-356.

Warrington, I. J., C.J. Stanley, D.S. Tustin, P.M. Hirst, and W.M. Cashmere. 1995. Light transmission, yield distribution and fruit quality in six tree canopy forms of 'Granny Smith' apple. J. Tree Fruit Prod. (In press.)

Westwood, M.N. and A.N. Roberts. 1970. The relationship between trunk cross-sectional area and weight of apple trees. J. Amer. Soc. Hort. Sci. 95:28-30.

Wilcox, J. 1937. Field studies of apple tree growth and fruiting. III. Some observations on the measurement of tree vigor. Sci. Agr. 17(11):657-669. 